Original Article

Received/Accepted Dates

29.05.2021/25.06.2021

DOI

10.52096/jsrbs.6.1.7.13.13
Journal of Social Research and Behavioral Sciences

Sosyal Araştırmalar ve Davranış Bilimleri Dergisi

ISSN:2149-178X

Volume: 7 Issue: 13 Year: 2021

\title{
Argümantasyon Yönteminin Uygulanması Sürecinde Karşılaşılan Sınırlılıkların Tartışılması
}

\author{
Bünyamin İSPİR \\ Atatürk Üniversitesi \\ Eğitim Bilimleri Enstitüsü \\ bünyamin.ispir14@org.atauni.edu.tr \\ ORCID: 0000-0002-0428-8887 \\ Ali YILDIZ \\ Atatürk Üniversitesi \\ Kazım Karabekir Eğitim Fakültesi \\ ayildiz@atauni.edu.tr \\ ORCID: 0000-0001-6241-2316
}

\section{Özet}

Çalışmanın amacı, argümantasyon yönteminin sınıf ortamında uygulanması sürecinde karşılaşılan sınırlılıkları tartışmaktır. Nitel veriler içeren çalışmada, doküman incelemesi yöntemi kullanılmıştır. Araştırma verileri; argümantasyon yönteminin sınırlılıklarıyla ilgili bulguları içeren bilimsel makale ve tezlerden elde edilmiş ve betimsel analiz yöntemine göre incelenmiştir. Verilerin toplanmasında dokümanlara erişme, dokümanların özgünlüğünü kontrol etme, dokümanları anlama, verileri analiz etme ve verileri kullanma şeklinde doküman incelemesine uygun olarak tüm aşamalar gerçekleştirilmiştir. Çalışmanın verilerini değerlendirme sürecinde, incelenen yayınların bulgularıyla birlikte araştırmacıların gözlemleri, sezgileri ve tecrübeleri göz önünde bulundurulmuştur. İncelenen dokümanlardan sağlanan bulgularla birlikte yapılan gözlem, uygulama ve edinilen deneyimlere dayanılarak argümantasyon yönteminin sınırlılıklarını en aza indirebilecek bazı önerilerde bulunulmuştur.

Anahtar Kelimeler: Argümantasyon, Bilimsel tartışma, Sınırlılık, Doküman incelemesi 


\title{
Discussing the Limitations During the implementation of the Argumentation Method
}

\begin{abstract}
The purpose of this study is to discuss the limitations encountered during the implementation of the argumentation method in the classroom environment. In the study containing qualitative data, the document analysis method was employed. The research data were obtained from scientific articles and theses containing the findings about the limitations of the argumentation method and were analyzed according to the descriptive analysis. In the collection of data, all stages were carried out in accordance with the document review, such as accessing documents, checking the authenticity of the documents, understanding the documents, analyzing and using the data. In the process of evaluating the data of the study, the observations, intuitions and experiences of the researchers along with the findings of the examined publications were taken into consideration. Based on the findings obtained from the examined documents, observation, practice and experience, some suggestions were made that could minimize the limitations of the argumentation method.
\end{abstract}

Keywords: Argumentation, Scientific discussion, Limitation, Document analysis

\section{Giriş}

Bilginin öneminin anlaşıldığı son zamanlarda bilim ve teknolojide çok hızlı gelişmeler yaşanmaktadır (Erduran \& Akçay, 2013). Bilim ve teknolojideki gelişmeleri birebir takip edebilmek; toplumun ekonomik, sosyal ve çevresel sorunlarını çözebilmek; araştıran, sorgulayan, bilinçli, yaratıcı ve kritik düşünme becerisine sahip bireylerin yetişmesini sağlamak devletler için önemlidir (Biber, 2012). Ülkemizde bireylerde olmasına ihtiyaç duyulan bu özelliklerin farkına varılması, eğitime yönelik yatırımların önem kazanmasına sebep olmaktadır. Ancak eğitime yönelik yapılan yatırımların artırılmasıyla birlikte bireylerin öğretimlerinin bireyselleştirilmesi gerekmektedir (Bozkurt, 2012). Bu doğrultuda Türkiye'de 2005-2006 eğitim-öğretim yılında ilköğretim kademelerine yönelik köklü bir değişim gerçekleşmiş, yapılandırmacı yaklaşımı temel alan bir öğretim programı kabul edilmiş ve bu programda öğrenci-etkinlik merkezli bir anlayış benimsenmiştir (MEB, 2005).

Öğrencilerin bahsi geçen yeni anlayışları anlamlı bir şekilde benimsemeleri için en etkin yöntem araştırma-sorgulama yaklaşımıdır (Köseoğlu, Tümay \& Budak, 2008). Araştırma sorgulama; delillerle beraber yüksek seviyede soruların sorulduğu, yoğun düşünme faaliyetlerinin gerçekleştiği ve karşılıklı fikir alışverişlerinin yapıldığı bir sistemdir (Çakan-Akkaş \& Kabataş- 
Memiş, 2020). Ayrıca araştırma sorgulama özgüvenli, fikirlerini rahatça dile getiren, üst düzey iletişim becerilerine sahip ve bilimsel sürecin içinde bizzat bulunan öğrencilerin yetiştirilmesine yardımcı olmaktadır (Kabataş-Memiş, 2017a). Belirtilen becerilere sahip bireyleri yetiştirmek için araştırma sorgulamanın yaşandığı ortam ve yöntemlere ihtiyaç vardır (Kabataş-Memiş, 2017b). Bu yöntemlerden biri de argümantasyon yöntemidir (Çetin, Kutluca \& Kaya, 2013).

Argümantasyon kelimesi ülkemiz literatürüne girdiği andan itibaren farklı ifadelerle isimlendirilmiştir. Orijinal adı "Science Writing Heuristic" olan yaklaşım Türkçe'ye ilk olarak Yaparak Yazarak Bilim Öğrenme (YYBÖ) şeklinde çevrilmiştir (Günel, Kabataş-Memiş \& Büyükkasap, 2010). Argümantasyon Tabanlı Bilim Öğrenme (ATBÖ) olarak dilimize çevrilen yöntem (Günel, Kıngır \& Geban, 2012); daha sonra bazı araştırmalarda Tartı̧̧ma Esaslı Öğretim Yaklaşımı (Aslan, 2010), Bilimsel Tartışma (Küçük \& Aycan, 2014; Şahin \& Hacıoğlu, 2010; Yakmacı-Güzel, Erduran \& Ardaç, 2009) veya Tartışmacı Söylev (Kaya \& Kılıç, 2008) olarak kullanılmıştır.

Bilinen ilk kullanımı 15. yy'da olan argümantasyon; sebep oluşturma, sonuç çıarma ve bunları tartışlan bir olaya uygulama süreci olarak tanımlanmıştır (Webster's Online Dictionary, t.y.). Argüman ise; bir düşünceyi, bir varsayımı veya bir fikri açıklamak için kullanılan kanıtlar olarak açıklanmıştır (Uysal, 2014). Kaya ve Kılıç’a (2008) göre argümantasyon; birbirine zit iki durum arasındaki karşıtlığı açıklamak için yapılan konuşma süreci veya mantıklı kararlara ulaşmak için yapılan etkinlikler dizisi iken Küçük ve Aycan'a (2014) göre karşıllklı iddiaların sunulduğu, gerekçelerin değerlendirildiği ve bir sonuca ulaşılmaya çalışıldığı süreçtir.

Normal bir tartışmanın argümantasyon başlığ 1 altında değerlendirilebilmesi için öne sürülen argümanların doğru şekilde oluşturulması gerekmektedir (Küçük \& Aycan, 2014). Bu doğrultuda argümantasyon, bir kazananı ve bir kaybedeni olan tartışma veya karşılıklı gerçekleşen münakaşadan farklıdır (Aymen-Peker, Apaydın \& Taş, 2012). Bu doğrultuda tartışmanın sonuç odakl1, argümantasyonun süreç odaklı olduğu söylenebilir (Arık \& Akçay, 2017). Argümantasyon sürecinde öğrenciler, eğitim ortamlarında verilen bilimsel tartışma etkinliklerini bireysel ya da grup içerisinde sözlü, yazılı veya online olarak farklı şekillerde gerçekleştirebilir (Demirel, 2015).

Sözlü argümantasyon; geleneksel eğitim anlayışında olduğu gibi öğretmen ile öğrenci arasında geçen soru sorma ve cevaplamadan farklı olarak öğretmenin iddia, veri, gerekçe gibi argüman bileşenlerini açığa çıkarmak için sorduğu bilimsel soru dizinini içerir. Bu sorular 'Niçin bu iddiada 
bulunuyorsunuz?', 'Bunun için nedeniniz nedir?', 'Görüşünüz için başka bir argümanınız var mı?’ ve 'Delilleriniz nelerdir?' şeklinde olabilir. Yazılı argümantasyon; kişinin iddiasını yazılı olarak ifade etmesine dayanır. Derinlemesine analizi gerektirdiğinden dolayı üst düzey becerilere ihtiyaç duyulmasının yanı sıra karşı taraftan gelebilecek sorular olmadığından dolayı cevapların önceden hazırlanması ve iddianın gerekçelerle daha güçlü savunulması gerekmektedir (Aktamış, 2017, s.14-15). Online argümantasyon ise; tartışmanın bilgisayar ve internet ortamına taşınarak öğretmen ile öğrencinin etkileşimini çevrimiçi ortamda mümkün kılan bir uygulamadır (Çelik, Gökçe, Aydoğan-Yenmez \& Özpınar, 2017). Sözlü, yazılı ve online argümantasyonda, bilgi ve becerilerin gelişmesi için öğrencilerin bir süreç içerisinde olması gerekmektedir. Tutarlı süreçleri kapsayan bu teknik, bireylerin becerilerini geliştirmelerini ve yeni beceriler kazanmalarını sağlamaktadır (Yakmac1-Güzel vd., 2009).

Aristoteles’ten bugüne fikirleri ifade etmek için kullanılan argümantasyon; öğrencileri meraklı ve aktif kılar, ayrıca onları cesaretlendirir (Küçük \& Aycan, 2014). Keçeci, Kırılmazkaya ve KırbağZengin'e (2011) göre bilimsel okuryazarlığı ve yapılandırmacı öğrenme süreçlerini destekler. Argümantasyon yaklaşımının kullanılması öğrenme ortamını öğrenci merkezli ve daha verimli, öğrencileri daha sosyal ve öğrenme-öğretme sürecini daha eğlenceli hale getirir (YeşildağHasançebi \& Günel, 2013). Bununla birlikte araştırma ve sorgulamayı temel alan argümantasyon; üst düzey düşünme gelişimine, öğrencilerin kendilerini daha rahat ifade etmelerine ve soyut bilgilere ilişkin daha somut bir anlayışın sağlanmasına imkân tanır (Çakan-Akkaş \& KabataşMemiş, 2020).

Kabataş-Memiş'in (2014) gerçekleştirdiği bir çalışmada argümantasyonun; öğrencilere geniş bir perspektif oluşturduğu, sorumluluk duygusu kazandırdığı ve akrandan öğrenmeyi sağladığ1 vurgulanmaktadır. Benzer şekilde argümantasyon; akıl yürütme becerisi kazandırmakta (KabataşMemiş, 2017b); hataları derinlemesine gözden geçirmek ve çözüme kavuşturmak için firsat tanımakta (Kaya \& Kılıç, 2008); anlamlı ve probleme dayalı öğrenmeyi, eleştirel düşünebilmeyi sağlamaktadır (Eyceyurt-Türk, Tüysüz \& Tüzün, 2018). Argümantasyon ayrıca derse aktif katılımı desteklemekte (Bilasa \& Taşpınar, 2018); kavramsal değişime ve doğru zihinsel modellerin oluşturulmasına imkân vermekte (Aslan, 2010); kavramsal yanılgıları düzeltmede yardımcı olmakta (Arık \& Akçay, 2017) ve tartışma isteğini artırmaktadır (Demirel, 2015). Bununla birlikte argümantasyonun; sosyal becerilerin gelişimine, bilime karşı olumlu yaklaşım geliştirmeye, karar verme becerilerine ve bilimsel okuryazarlığa katkıları bulunmaktadır (Uysal, 2014). 
Argümantasyonun faydaları göz önünde bulundurulduğunda eğitim-öğretim ortamlarının bilimsel tartışma uygulamalarına uygun şekilde düzeltilmesi gerektiği söylenebilir.

Argümantasyonun eğitim-öğretim hayatına dâhil edilmesi, Toulmin'in önerdiği tartışma modelini içeren ve 1958'de yayımlanan “Tartışmanın Kullanımı (The Uses of Argument)” adlı kitap ile gerçekleşmiştir. Felsefecilerin 1958'e kadar sormadığı soruları sormaya başlayan Toulmin'in tartışma modeli iddia, veri, garanti, destek, çürütücü ve niteleyen olmak üzere altı bileşenden oluşmaktadır (Aldağ, 2006; Eyceyurt-Türk vd., 2018). Bir argümanın oluşturulabilmesi için iddia, veri ve gerekçe gerekli iken destekleyici, niteleyici ve çürütücü argümanın geçerliliğine katkı sağlamaktadır (Kaya \& Kılıç, 2008). Yani model üç ana ve üç yardımcı öğeden oluşmaktadır. Karmaşık ya da derin tartışmalarda yardımcı ögelere rastlamak mümkündür (Coşkun \& Tiryaki, 2011). Temel veya yardımcı bileşenlerin argümantasyon sürecinde olması veya olmaması bir argümanın kuvvetini belirlemektedir. Bu doğrultuda daha fazla bileşene sahip argümanların daha güçlü olduğu söylenebilir (Tümay, 2008). Diğer bir ifadeyle zayıf argüman; ilişkisiz gerekçelendirmeleri içerirken güçlü argüman; çoklu gerekçelendirmeleri içermektedir (KabataşMemiş, 2017b).

Toulmin'in ortaya attığı bileşenlerle ilgili alan yazında farklı terimlere rastlanmaktadır. Örneğin; veri, bilgi veya delil; garanti, teminat, gerekçe veya haklı neden; niteleyici, sınırlayıcı; reddedici, çürütme veya karşıt argüman olarak ifade edilebilmektedir (Arık \& Akçay, 2017). Bileşenlerin şematize edilmiş hali (Toulmin, 2003, s.97) ve açıklamaları aşağıdaki gibidir (Sevgi \& Şahin, 2017).

Şekil 1. Toulmin Tartışma Modeli

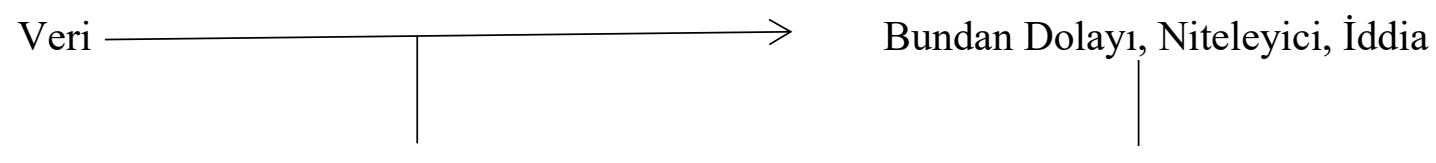

Çünkü Olmazsa

Garanti / Gerekçe

Çürütücü

Dolayı / Yüzünden

Destekleyici 
1. Veri: Tartışmanın temel öğelerinden biri olan iddiayı destekleyen olgulardır.

2. İddia: Verilere dayandırılarak ortaya atılan fikirdir.

3. Gerekçe: Verilerin iddiayı nasıl desteklediğinin gösterilmesidir.

4. Niteleyici: İddianın sınırlarını belirleyen büyük olasılıkla, muhtemelen, belki ve kesinlikle gibi ifadelerdir.

5. Çürütme: İddiaların geçerliliğini kaybettiği durumlardır.

Açıklamalar 1şığında Toulmin'in (2003, s.97) en sık kullanılan argüman örneği Şekil 2'de verilmiştir.

Şekil 2. Toulmin Tartışma Model Örnĕ̆i

$\begin{aligned} & \text { Harry, Bermuda' da doğmuştur } \\ & \text { İngiliz'dir }\end{aligned}|\longrightarrow \quad|$ büyük olasılıkla, Harry

Çünkü genellikle

Bermuda'da doğanlar $\quad$ Fakat onun ailesi yabanc1 veya İngiliz

İngiliz vatandaşı olur vatandaşlığına sonradan geçmiş olabilir

Bermuda, İngiltere'nin

en çok göç alan yeridir

Şekil 2 incelendiğinde Toulmin, 'Harry, İngiliz vatandaşıdır' iddiasını 'Harry, Bermuda' da doğmuştur' verisine dayandırmıştır. 'Genellikle Bermuda'da doğanlar İngiliz vatandaşı olur' ifadesi iddia ve veri arasındaki nedenselliği açıkladığından gerekçe olarak değerlendirilmelidir. Gerekçe, 'Bermuda, İngiltere'nin en çok göç alan yeridir' ifadesi ile kuvvetlendirilerek desteklenmiştir. Ayrıca iddianın geçerli olduğu koşulları belirten 'büyük olasılıkla' ifadesi, niteleyici bileşenini ortaya koyarken, 'Onun ailesi yabancı veya İngiliz vatandaşlığına sonradan geçmiş olabilir’ ifadesi, çürütücü bileşenini oluşturmaktadır.

Toulmin'in tartışma modeli öğretmenlere tartışmanın hangi öğelerden oluştuğunu ifade etmede, bilimsel tartışmanın nasıl gerçekleştiğini göstermede ve bileşenler arasındaki ilişkileri anlamlandırmada büyük kolaylıklar sağlar. Ayrıca model; argümantasyonun etkileşimli bir akıl 
yürütme süreci olarak algılanmasını kolaylaştırır, öngörülemeyen varsayımların açıç̧a ortaya konmasına yardımcı olur, eleştirel bir bakış açısı kazandırır, tartışma becerilerinin geliştirilmesini destekler ve argümantasyon sürecini yavaşlatarak analizi mümkün kılar (Aldağ, 2006).

Argümanların değerlendirilmesi, öğrencilerin konuyla alakalı kavramsal anlamaları ve farklı fikirleri analiz etmeleri hakkında bilgi vermesi açısından önemlidir. Argümantasyon kalitesinin değerlendirilmesinde en çok kullanılan analitik çerçeve, Toulmin tartışma modelini esas alan ve Erduran, Simon ve Osborne (2000) tarafından geliştirilen analiz rubriğidir (Altun \& Aydın, 2019, s.94). Argümantasyon kalitesini değerlendirmek için kullanılan analitik çerçeve aşağıdaki gibidir (Erduran, Simon \& Osborne, 2004, s.16).

Seviye 1: Birinci seviye argümantasyon, bir iddiaya karşı başka bir iddiayı içerir.

Seviye 2: İkinci seviye argümantasyon, bir iddiaya karşı veri, gerekçe ve destekleyicileri içerisinde barındıran başka bir iddiayı içerir, fakat hiçbir çürütücü içermez.

Seviye 3: Üçüncü seviye argümantasyon, bir iddiaya karşı veri, gerekçe, destekleyiciler ve nadiren zayıf çürütücüleri içerisinde barındıran iddialar veya karşıt iddialar dizinini içerir.

Seviye 4: Dördüncü seviye argümantasyon, açıkça tanımlanmış çürütücüleri içerisinde barındıran bir iddiayı belirtir. Böyle bir argüman, birkaç iddia ve karşıt iddiayı bulundurabilir.

Seviye 5: Beşinci seviye argümantasyon, birden fazla çürütücüyü içerisinde barındıran kapsamlı bir argümanı ifade eder.

Değerlendirme aracı; argüman kalitesini ölçmek için argüman bileşenlerinin kullanımlarına bağlı olarak seviyelere ayrılmıştır. En düşük seviye olan 1'de öğrenciler yalnızca bir iddia ve karşıt bir iddiada bulunurken en yüksek seviye olan 5'te öğrenciler argümanlarında birden fazla çürütücü kullanırlar (Altun \& Aydın, 2019, s.94). Analiz rubriği, bilimsel tartışma kalitesini değerlendirmek için kullanılırken alanyazında belirtilen bazı sınırlılıklara dikkat edilmelidir.

Toulmin'in tartışma modelinde temelde üç sorun olduğu söylenebilir. İlk olarak modeldeki argüman bileşenlerinin hukuk, biyoloji, psikoloji gibi bir alanda belirlenmesi ve analiz edilmesinden dolayı bileşenlerle ilgili farklı tanımlamaların yapılmasıdır. $\mathrm{Bu}$, argümantasyon analizini ve değerlendirilmesini güç hale getirmektedir. Diğer bir sorun değerlendirme aşamasında hangi ölçütlerin kullanılması gerektiğinin açık olmamasıdır. Ayrıca tartışmalar; modeldeki gibi sıralı ilerlemeyebileceğinden dolayı model, uzun ve karmaşı tartışmalarda yetersiz 
görülmektedir. Bunların yanı sıra modelde; veri ile gerekçe arasındaki etkileşimin nasıl kurulacağının açık olarak belirtilmemesi ve tartışmayı etkileyebilecek etkenlerin bileşenlerle temsil edilmemesi gibi olumsuzluklar yer almaktadır (Coşkun \& Tiryaki, 2011). Toulmin'in tartı̧̧ma modeli alan bağımlılık, bileşenlerin açık olmaması ve analize ilişkin eksiklikler gibi dezavantajlarına rağmen eğitimdeki tartı̧̧ma analizlerinde en çok kullanılan model olarak yer almakta ve bazı yönleriyle geleneksel eğitimden ve diğer yöntemlerden ayrılmaktadır (Aldağ, 2006; Çetinkaya \& Taşar, 2017).

Genellikle suç bilimi ve hukuk alanında kullanılan argümantasyon stratejisi (Çetinkaya \& Taşar, 2017), bireylerin bilimsel tartışma sürecine dâhil olmalarını sağlaması yönüyle diğer yaklaşımlardan ayrılmaktadır (Demircioğlu \& Uçar, 2012). Argümantasyonu geleneksel uygulamalardan ayıran özellik; öğrencilerin iddialarına mantıksal gerekçeler bulmalarına yardımcı olan, karşıt fikirleri çürütmeye dayanan ve farklı fikirlere karşı anlayışı davranmayı temel alan etkinliklerin olmasıdır. $\mathrm{Bu}$ etkinlikler; ifadeler tablosu, kavram haritası, deney raporu, karikatürlerle yarışan teoriler, hikayeler ve fikirlerle yarışan teoriler, argüman oluşturma, tahmin et-gözle-açıkla, delil kartları ve deney tasarımı şeklinde sıralanabilir (Demirel, 2015).

1. İfadeler Tablosu: Konuyla alakalı tablo öğrencilere verilir ve bu ifadelerden birinin seçilmesi istenir. Ardından neden o ifadenin seçildiği tartışılır.

2. Kavram Haritası: Konuyla ilgili öğrencilerin kavramsal algılamaları alanyazın taranarak bir kavram haritası hazırlanır. Daha sonra haritadaki kavram ve kavramlar arası ilişkiler sınıf içerisinde tartışılır.

3. Deney Raporu: Başka kişiler tarafından hazırlanan deney raporu, öğrencilere verilerek rapor üzerinde tartış1lır.

4. Karikatürlerle Yarışan Teoriler: İki veya daha fazla teori, karikatür şeklinde öğrencilere verilerek tartışmaları sağlanır.

5. Hikâye ile Yarışan Teoriler: Öğrencilere yazılı hikâyelerle teoriler verilir ve bu teorileri tartışmaları istenir.

6. Fikirler ile Yarışan Teoriler: İki veya daha fazla fiziksel olay öğrenciye sunulur ve iki açıklama yapılır. Daha sonra öğrencilerden açıklamalardan birini seçmelerine ve tartışmalarına olanak tanınır. 
7. Argüman Oluşturma: Fiziksel bir olay öğrenciye verilerek olayla alakalı bir açılama yapılır ve dört ifade sunulur. Daha sonra öğrencilerin ifadelerden birini seçmeleri ve tartışmaları sağlanır.

8. Tahmin Et- Gözle-Açıla

9. Deney Tasarımı (Aslan, 2010).

Süreçte belirtilen etkinlikleri gerçekleştirmenin yanı sıra öğrenci ve öğretmenlerin bazı rol ve sorumlulukları bulunmaktadır. Öğrenci, argümantasyon sürecinde bilginin kaynağını araştıran, sorgulayan, açıklamalar yapan, tartışan ve bunları çıktıya dönüştüren birey rolündeyken (ÇakanAkkaş \& Kabataş-Memiş, 2020) öğretmen, öğrenciye rehberlik eden, sınıf içinde tartışma sürecini başlatan ve yönlendiren, öğrencilerin sorgulamalarını ve düşünmelerini sağlayan birey rolündedir (Çetinkaya \& Taşar, 2017; Küçük \& Aycan, 2014). Öğrencinin sınıf içerisinde aktif olma düzeyi, öğretmenin aktifliğiyle doğru orantılıdır. Öğretmenin sınıfta yüksek seviyede sorular sorması, bilimsel tartışmaların düzeyini ve yoğunluğunu artırmaktadır (Günel vd., 2012). Öğretmenler; öğrencilerin sunduğu düşünceleri yargılamadan dinlemeli, fikirlerine saygı duymalı, düşüncelerine yön vermemeli ve sorduğu sorularla tartışmanın devamlılığını sağlamalıdır (Sevgi \& Şahin, 2017). $\mathrm{Bu}$ doğrultuda, öğretmenlerin argümantasyon sürecinde nasıl bir yol izleyeceklerine yönelik eğitim almasının önemi ortaya çıkmaktadır (Demirel, Somyürek \& Yılmaz, 2017). Öğretmenlere verilecek eğitimlerin yanı sıra öğrenciler, küçük yaşlarda argümantasyon uygulamalarıyla bütünleştirilmelidir (Namdar \& Demir, 2016).

İlkokul (Öğreten \& Uluçınar-Sağır, 2014), ortaokul (Topçu \& Atabey, 2017; Torun \& Şahin, 2016), lise (Çetin vd., 2013; Eyceyurt-Türk vd., 2018) ve üniversite (Erkol, Kışoğlu \& Gül, 2017; Tümay \& Köseoğlu, 2010) düzeyinde olmak üzere her kademede yapılan araştırmaların sonuçları göz önünde bulundurulduğunda argümantasyon etkinliklerinin akademik başarıya olumlu yönde etki ettiği gözlenmiştir. Ayrıca uygun yönlendirmelerle argümantasyon aktivitelerinin hem doğrudan hem de dolaylı olarak öğrencilerin eleştirel düşünme ve akıl yürütme becerilerine, kavram yanılgılarını düzeltmelerine, çevrelerindeki insanlarla sağlıklı iletişim kurmalarına ve çalışma becerilerine katkıda bulunacağı düşünülmektedir. 


\section{Çalışmanın Amacı}

Çalışmanın amacı, argümantasyon yönteminin sınıf ortamında uygulanması sürecinde karşılaşılan sinırlılıkları tartışmaktır.

\section{Yöntem}

Araştırmada argümantasyon yaklaşımına yönelik yapılan çalışmaların incelenmesi amaçlandığından nitel araştırma yöntemlerinden doküman incelemesi kullanılmıştır. Doküman incelemesi, araştırılması hedeflenen olay veya olgular hakkında bilgi içeren yazılı materyallerin analizini kapsar ve nitel araştırmada tek başına veri toplama yöntemi olarak kullanılabilir. Anılar, günlükler, mektuplar gibi kişisel belgelerin yanı sıra magazin, dergi, kitap, yönerge, plan, ödev,

resmî belge gibi pek çok doküman veri kaynağı olabilir. Çeşitli araştırmalarda sıklıkla karşılaşılan ve bir araştırma yöntemi olan doküman incelemesinin düşük maliyetli olması, uzun süreli analizi mümkün kılması, örneklem büyüklüğü sağlaması gibi güçlü yönlerinin yanı sıra olası yanlılık, eksiklik ve ulaşılabilirlik gibi zayıf yönleri mevcuttur (Yıldırım \& Şimşek, 2018, s.189-194).

Çalışmada süreç; doküman incelemesinin aşamalarına uygun olarak sırasıyla dokümanlara erişme, dokümanların özgünlügünü kontrol etme, dokümanları anlama, verileri analiz etme ve verileri kullanma şeklinde gerçekleştirilmiştir. Araştırma verileri; argümantasyon yönteminin sınırlılıklarıyla ilgili bulguları içeren bilimsel makale ve tezlerden elde edilmiş ve betimsel analiz yöntemine göre incelenmiştir.

\section{Bulgular}

Çalışmada, bilimsel tartışmalarla ilgili yapılan araştırmaların (Aksu, 2019; Aktamış \& Atmaca, 2016; Apaydın \& Kandemir, 2018; Aydemir, Karakaya-Cırıt, Kaya \& Azger, 2018; Aydın \& Kaptan, 2014; Demir, 2019; Güler, 2016; Hiğde \& Aktamış, 2017; İlk, 2019; Kaçar, 2019; Karaer, Karademir \& Tezel, 2019; Kırçiçek, 2019; Korkmaz, 2020; Namdar \& Tuskan, 2018; Özcan, Aktamış \& Hiğde, 2018; Süküt, 2020; Türkmenoğlu \& Çopur, 2021; Yüksel, 2019) yazılı dokümanları incelenmiştir. İncelemeler sonucunda, argümantasyonun uygulanma sürecinde bazı sınırlılık ve dezavantajlarla karşılaşıldığı bulgusuna ulaşılııştır. Araştırmalarda yer verilen zayıf yönler genel hatlarıyla öğrenciden kaynaklanan, grupla çalışmaktan kaynaklanan, öğretmenden 
kaynaklanan, eğitim ortamından kaynaklanan, yöntemden kaynaklanan ve müfredattan kaynaklanan sınırlılıklar şeklinde sınıflandırılabilir. Sınırlılıklara ait genel sınıflandırma Tablo 1' de verilmiştir.

Tablo 1. Argümantasyon Araştırmalarının Sınırlılıklarına Göre Sınıflandırılması

\begin{tabular}{|c|c|}
\hline Kaynak & Sinırlılık \\
\hline \multirow{7}{*}{$\begin{array}{l}\text { Öğrenciden } \\
\text { kaynaklanan } \\
\text { sinırlılıklar }\end{array}$} & Yeterli bilgi düzeyine sahip olmama / Bilgi düzeyinin zayıflığ1 \\
\hline & Özgüven eksikliği / Çekingen tavır / Utangaç olma \\
\hline & Tartışma kurallarının bilinmemesi \\
\hline & Hayal gücü \\
\hline & İş bölümü kültürünün olmaması \\
\hline & Ön bilgi eksikliğinin olması / Ön öğrenmelerin gerekli olması \\
\hline & $\begin{array}{l}\text { Bireyler arası uyumsuzluk / Akranlarla anlaşamama / Fikir ayrılıklarının } \\
\text { oluşması }\end{array}$ \\
\hline \multirow{3}{*}{$\begin{array}{l}\text { Grupla } \\
\text { çalışmaktan } \\
\text { kaynaklanan } \\
\text { sınırlılıklar }\end{array}$} & Grup arkadaşlarıyla ortak bir iddia ortaya koyamama \\
\hline & Grup arkadaşlarıyla ortak bir araştırma sorusuna ulaşamama \\
\hline & Grup üyelerinin fazla olması \\
\hline \multirow{6}{*}{$\begin{array}{l}\text { Öğretmenden } \\
\text { kaynaklanan } \\
\text { sinırlılıklar }\end{array}$} & Sınıf hâkimiyetinin sağlanamaması \\
\hline & Deneyimsiz olma / Öğretmen yeterlilikleri \\
\hline & Geri bildirimde yetersiz kalma \\
\hline & Bireysel ölçme ve değerlendirmenin eksik olması \\
\hline & Tartışma sırasında yanlış bilgi kodlanabilme durumu \\
\hline & $\begin{array}{l}\text { Tartışmada konu sınırlılıkları belirlenmediği takdirde konu dışına } \\
\text { çıkabilme durumu }\end{array}$ \\
\hline \multirow{4}{*}{$\begin{array}{l}\text { Eğitim } \\
\text { ortamından } \\
\text { kaynaklanan } \\
\text { sinırlılıklar }\end{array}$} & $\begin{array}{l}\text { Sınıfların kalabalık olması / Kalabalık sınıf uygulamalarında gürültü } \\
\text { oluşması }\end{array}$ \\
\hline & Sınıf ortamlarında uygulamanın güç olması \\
\hline & Sınıf düzeninin bozulması \\
\hline & Yer problemi \\
\hline & İçerik birimine uygun olmama / Öğrenci seviyesine uygun olmama \\
\hline
\end{tabular}




\begin{tabular}{|c|c|}
\hline \multirow{4}{*}{$\begin{array}{l}\text { Yöntemden } \\
\text { kaynaklanan } \\
\text { sinırlılıklar }\end{array}$} & Kafa karışıklığına sebep olma \\
\hline & Bireysel farklılıklara uyumlu olmama \\
\hline & Dikkat dağınıklığına yol açma \\
\hline & Argümanı destekleyememe \\
\hline & Karşıt argümanı çürütememe \\
\hline \multicolumn{2}{|l|}{ Müfredattan } \\
\hline $\begin{array}{l}\text { kaynaklanan } \\
\text { sinırlılıklar }\end{array}$ & Müfredatı yetiştirememe kaygısı / Zaman alıcı olması \\
\hline
\end{tabular}

Konu hakkında yeterli bilgi düzeyine sahip olmayan öğrenciler, argümantasyon uygulamasına dâhil olmamakta veya düşüncelerini söylemekten çekinmektedir. Öğrenciler, genellikle "Yanlış bir şey söylersem arkadaşlarım bana güler mi, benimle dalga geçer mi?” endişesi taşıdıklarından dolayı düşüncelerini açıkça ifade edememektedir (Namdar \& Tuskan, 2018). Bu yüzden her öğrencinin konuya ve tartışma ortamına katılması beklenemez. Bazen konu hakkında herhangi bir terim, kavram veya bilgiye sahip olmamak, tartışmanın rengini değiştirebilir. Ayrıca süreçte, öğrencilerin argümantasyon uygulamalarına ilişkin alt yapılarının olmamasının yanı sıra bir önceki yıl aynı konuyla alakalı temel kavramları detaylı bir şekilde anımsamamaları, argümantasyon yönteminin sınıf ortamında kullanılmasını zorlaştırabilir.

Sınıf içerisinde kendini gösteremeyen, özgüven eksikliği yaşayan ve utanan öğrenciler bulunabilir. Argümantasyon yöntemi, belirtilen öğrenciler için zor bir uygulamaya dönüşmekte ve uygulama sürecinde soru sormaktan çekinen öğrenciler, derse katılmakta istekli davranmamaktadır (Aydemir vd., 2018; Güler, 2016). Ayrıca öğrencinin kelime haznesinin dar olması, yeterli bilgiye sahip olmaması, yöresel bir dil kullanması ve öğretmenin otoriter davranması öğrencilerin rahat bir şekilde düşüncelerini ifade etmelerini engelleyebilir. Bununla birlikte farklı fikirlere tahammül edememe ve saygılı olmama, en iyi fikirlerin tartışmalar sonucunda ortaya çıkabileceğini idrak edememe, tartışma çerçevesinin çizilmemesi ve bilimsel yönden yetersiz olma tartışmaları münakaşaya dönüştüren etmenler arasındadır. Bu yüzden ders sürecinde öğrencilere sorulan sorular planlı bir tartışmanın parçası olmazsa sınıfta etkili bir tartışma ortamı sağlanamaz.

Tartışılan konu hakkında her öğrenci farklı düşüncelere sahip olabilir. Öğrenciler, düşünce farklılıklarını tartışarak net bir kanıya varabilir ancak birbirlerinin düşüncelerine saygılı 
olmadıkları durumlarda sorunlar meydana gelebilir. Gruplarda baskın öğrencilerin, grup lideri olarak düşünceleriyle diğer öğrencilere hâkim olmaya çalışması, o öğrencilerin geri planda kalmasına yol açmaktadır (Güler, 2016). Ayrıca grup çalışmalarında öğrenciler, ortak bir iddia ileri sürmede ve ortak bir araştırma sorusu oluşturmada zorlanmaktadır (Kaçar, 2019). Bununla birlikte grupların kalabalık olması iş paylaşımında problemler çıkarabilir ve bu durum, tartışma sayısını artıracağından dolayı yanlış düşüncelerden vazgeçilme süresi uzayabilir.

Öğrencilerin ön bilgi eksikliklerinin bulunması ve hazırbulunuşluklarının farklı olması argümantasyon yönteminin dezavantajları arasındadır (Hiğde \& Aktamış, 2017; Türkmenoğlu \& Çopur, 2021). Konuyla alakalı herhangi bir bilgiye sahip olmama, öğrencilerin bilimsel tartışmaya katılımlarını engellemektedir. $\mathrm{Bu}$ yüzden ön öğrenmelerin gerekli olduğu durumlarda argümantasyon uygulamaları başarısızlıkla sonuçlanmaktadır (Apaydın \& Kandemir, 2018).

Öğrencilerin grupta ya da argümantasyon uygulamasında anlaşamadığı kişiler varsa tartışmalar eğitim amacının dışına çıkabilir ve uygulama sırasında kavgaya varan derin fikir ayrılıkları meydana gelebilir. Öğrenciler arasındaki tartışmalar, ders ve okul dışına taşınabileceğinden istenmeyen disiplin problemleri ortaya çıabilir. Böylece argümantasyon etkinlikleri karşılıklı etkileşim, sosyal iletişim ve bilgi alışverişinden ziyade fikir çatışmalarına dönüşebilir. Diğer taraftan grup halinde düzenlenen etkinlikler, kişiler arası birbirini anlamama veya anlatamamadan kaynaklı küslükler meydana getirebilir. Demir'in (2019) gerçekleştirdiği çalışmada uygulamaya katılan öğrencilerden birinin "Bazen ben kendi söylemek istediğimi anlatırken zorluk yaşadım bazen de onlara anlatırken zorluk yaşadım ama yine de iyi oldu." şeklinde görüş belirtmesi bu fikri desteklemektedir.

Öğretmen, argümantasyon sürecinde; sınıf disiplinini sağlama, geri bildirimde bulunma, tartışmayı yönetme, ölçme ve değerlendirme rollerini üstlenen kişidir. Öğretmenin plansız bir tartışma başlatması, yönteme ve konuya hâkim olmaması, yöntemin bilimsel altyapısını yeterince tanımaması ve öğrenciler tarafından tartışma kültürünün bilinmemesi (izin alarak konuşmak, sırayla konuşmak vb.), sınıf disiplinini sağlamayı zorlaştıran bazı faktörlerdir. Öğretmenin bilgi birikiminin yeterli olmadığı durumlarda tartışmayı yönlendirebilme ihtimali zayıftır. Argümantasyon yönteminin bilgi ve deneyim gerektirmesinden dolayı (Türkmenoğlu \& Çopur, 2021) öğretmen, yöntem hakkında herhangi bir deneyime sahip değilse fikirler test edilmeden askıda kalmaktadır. Bu yüzden tartışma sırasında yapılan hataların gözden kaçırılmadan 
düzeltilmesi ve dönüt sağlanması gerekmektedir (Namdar \& Tuskan, 2018). Yani tartışma iyi kontrol edilemez ve doğru geri bildirimler verilmezse öğrencide bilgi kirliliği oluşmaktadır. Ayrıca bireysel değerlendirmenin zor olması (Hiğde \&Aktamış, 2017), tartışma sırasında yanlış bilgilerin kodlanabilmesi (Karaer vd., 2019) ve konunun çerçevesinin çizilmediği durumlarda konu dışına çıkılması (Apaydın \& Kandemir, 2018) argümantasyon yönteminin öğretmenden kaynaklanan diğer olumsuz yönleri olarak göze çarpmaktadır.

Öğrenci merkezli yöntemlerin çoğunda karşılaşılan dezavantajlardan birisi, kalabalık sınıflarda uygulanmalarının zor olmasıdır. Çok kalabalık sınıflarda her öğrenciye söz hakkı vermek, var olan veya ortaya çıkan tüm argümanları değerlendirmek ve etkinlikleri gerçekleştirmek güç olmaktadır. Ayrıca argümantasyon yönteminin uygulanması aşırı gürültü oluşmasına neden olmaktadır (Yüksel, 2019) ve bu durum, tartışmaları karmaşık hale getirmekte, tartışmaların anlaşılma düzeylerini düşürmektedir (Güler, 2016).

Argümantasyon, diğer öğrenci merkezli yöntemlerde olduğu gibi ders öncesi hazırlık ve ders sonrası geri dönütler gerektirmektedir. Bu yüzden yöntem, öğretmene ayrı bir yük oluşturmakta ve uygulamanın sınıf ortamında yapılmasını bazı öğretmenler için zorlaştırmaktadır. Ayrıca yöntemin uygulanması birden fazla görüşün tek tek incelenmesi, tartışılması ve değerlendirilmesini gerektirdiğinden dolayı güç olabilmektedir (Aydemir vd., 2018). Bununla birlikte grup üyelerinin fazla olması (Aydın \& Kaptan, 2014), sınıf düzeninin bozulması ve yer problemi bilimsel tartışmanın eğitim ortamından kaynaklanan diğer zayıf yönlerini oluşturmaktadır (Özcan vd., 2018).

Küçük yaş gruplarında, yaşanan kültüre uygun olmayan durumlarda, çok soyut ve bilimsel olan konuların tartışılması güç olacağından ve bazı derslerde tartışmaya uygun içerik saptanamayacağından dolayı argümantasyon etkinliklerini her derse ve konuya uygulamak mümkün olmamaktadır (Türkmenoğlu \& Çopur, 2021). Bununla birlikte konuyla ilgili yeterli altyapı ve bilgi birikimine sahip olmayan öğrencilerin farklı öğrencilerden gelen alternatif düşüncelerden dolayı kafaları karışmaktadır. Diğer taraftan argümantasyon yöntemi, bireysel farklılıklara uyumlu olmamakta ve dikkat dağınıklığına yol açmaktadır (Aktamış \& Atmaca, 2016; Korkmaz, 2020). Ayrıca argümanları destekleyememe ve karşıt argümanları çürütememe, yöntemden kaynaklanan diğer olumsuz yönler arasındadır (Kaçar, 2019) 
Argümantasyon becerisi geliştirmek uzun bir süreç gerektirmektedir. Müfredat yetiştirme kaygısı, zaman kısıtlaması ve TEOG gibi sınavlar nedeniyle daha çok soru çözmeye vakit ayrılması özellikle yedinci ve sekizinci sınıf öğrencileri için argümantasyon uygulamasında zorluklar oluşturmakta ve konu yetiştirme kaygısı, bu tür uygulamaları geri plana atmaktadır. Ayrıca bilimsel tartışmalar, saatlerce sürebileceği için ders saatlerine entegre edilememektedir (Namdar \& Tuskan, 2018). Bu yüzden bir ders saati, uygulamaların yarım kalmasına sebep olmaktadır.

İncelenen yayınların bulguları, araştırmacıların gözlem, sezgi ve tecrübeleri göz önünde bulundurulduğunda argümantasyon yönteminin daha etkili kullanılmasının ve dezavantajlarının azaltılmasının veya ortadan kaldırılmasının aşağıdaki koşulların sağlanmasıyla mümkün olabileceği düşünülmektedir.

1. Argümantasyon etkinlikleri, öğrencilerin sözlü ve yazılı anlatım becerileri dikkate alınarak hazırlanmalıdır.

2. Argümantasyon uygulamasından önce, öğrencilerin kendi argümanlarını ortaya koyabilecek ve destekleyecek etkinlikler kullanılmalı veya öğrencilere konuyla ilgili sorular verilerek öğrencilerin derse daha hazırlıklı gelmeleri sağlanmalıdır.

3. Öğretmenler, ders öncesinde tartışmanın bütün aşamalarını dikkate alarak bir tartışma planı oluşturmalıdır.

4. Sınıf ortamında baskıcı-otoriter bir anlayıştan kaçınılmalı ve öğrencileri tartışmaya teşvik eden bir ortam sağlanmalıdır.

5. Argümantasyon yöntemi, farklı ders ve konulara uyarlanarak öğrencilerde tartışma kültürü oluşturulmalıdır. Ayrıca argümantasyon ortamında tartışma kültürüne uygun davranan öğrencilerin davranışları takdir edilerek kurallara uymayan öğrencilerin benzer davranışlar sergilemeleri özendirilmelidir.

6. Öğretmenler, sınıf hâkimiyetini artırmak için konuyla alakalı ön okumalar ve araştırmalar yaparak güncel örnekleri edinmeli, yöntemin alt aşamalarını ve uygulama şeklini gözden geçirmelidir.

7. Tartışmaya çok katılmayan öğrencileri belirlemek, onların tartışmalara dâhil olmasını sağlamak, öğretmenin kontrolünü kolaylaştırmak, iş bölümünü artırmak ve hep aynı öğrencilerin ön plana çıkmasını engellemek için kalabalık sınıflarda 3-4 kişilik küçük heterojen gruplar oluşturulmalıdır. 
8. Öğretmen, bilgi kirliliğinin önüne geçmek için uygulama esnasında tespit ettiği durumlarla ilgili dönütleri tartışmanın hemen akabinde zaman ayırarak bireysel değil genel hatlarıyla vermelidir.

9. Öğretmenlerin hem alan hem de pedagojik bilgilerinin geliştirilmesi için hizmet içi eğitimler düzenlenmelidir.

\section{Sonuç ve Öneriler}

Çalışmada, argümantasyonla ilgili yapılan araştırmaların (Aksu, 2019; Aktamış \& Atmaca, 2016; Apaydın \& Kandemir, 2018; Aydemir vd., 2018; Aydın \& Kaptan, 2014; Demir, 2019; Güler, 2016; Hiğde \& Aktamış, 2017; İlk, 2019; Kaçar, 2019; Karaer vd., 2019; Kırçiçek, 2019; Korkmaz, 2020; Namdar \& Tuskan, 2018; Özcan vd., 2018; Süküt, 2020; Türkmenoğlu \& Çopur, 2021; Yüksel, 2019) öğrenci veya öğretmen görüşlerini içeren nitel bulguları incelenmiştir. İncelemeler sonucunda, argümantasyon yöntemine yönelik bazı sınırlılık ve dezavantajlarla karşılaşılmıştır. Çalışmada, görüşmeler sonucunda elde edilen sınırlılıklar; öğrenciden kaynaklanan, grupla çalışmaktan kaynaklanan, öğretmenden kaynaklanan, eğitim ortamından kaynaklanan, yöntemden kaynaklanan ve müfredattan kaynaklanan sinırlılıklar şeklinde sınıflandirılmıştır.

İncelenen araştırmaların bulgularıyla birlikte yapılan gözlem, uygulama ve edinilen tecrübeler dikkate alındığında, argümantasyon yönteminin daha etkili kullanılmasında ve sınıf ortamında uygulanmasında karşılaşılan sınırlılıkların azaltılmasının veya ortadan kaldırılmasının bazı şartların sağlanmasıyla mümkün olabileceği düşünülmektedir. Ortaya konan koşullar aynı zamanda bu çalışmanın önerileridir.

Argümantasyon etkinliklerinin öğrencilerin sözlü ve yazılı anlatım becerileri dikkate alınarak hazırlanması, uygulamadan önce öğrencilerin kendi argümanlarını ortaya koyabilecek ve destekleyecek etkinliklerin kullanılması ve öğrencilere konuyla ilgili sorular verilerek derse daha hazırlıklı gelmelerinin sağlanması argümantasyonun zayıf yönlerinin bir kısmını giderebilecek etki yaratabilir. Ayrıca öğretmenler tarafından tartışmalar için planlamaların yapılması ve baskıcı eğitimden kaçınılarak tartışmalara katılmayı teşvik eden bir ortamın oluşturulması halinde argümantasyonun diğer olumsuz yönlerinin ortadan kaldırılabileceği belirtilmektedir. Yöntemin farklı ders ve konulara uyarlanarak öğrencilerde tartışma kültürünün oluşturulması, tartışma 
kültürüne uygun davranan öğrencilerin davranışlarının takdir edilerek kurallara uymayan öğrencilerin benzer davranışlar sergilemelerinin özendirilmesi, öğretmenlerin konuyla alakalı ön okumalar ve araştırmalar yaparak güncel örnekleri edinmeleri, yöntemin alt aşamalarının ve uygulama şeklinin gözden geçirilmesi durumunda sınırlılıkların en aza indirgenebileceği iddia edilmektedir. Bununla birlikte kalabalık sınıflarda 3-4 kişilik heterojen grupların oluşturulması, öğretmenlerin dönütleri tartışmanın hemen akabinde zaman ayırarak bireysel değil genel hatlarıyla vermesi ve hem alan hem de pedagojik bilgilerin gelişmesi için yöntemle ilgili hizmet içi eğitimlerin düzenlenmesiyle dezavantajların giderilebileceği düşünülmektedir. Sıralanan şartların tedbir olarak alınması veya yerine getirilmesi durumunda argümantasyon yönteminin etkililiğinin artabileceği söylenebilir.

\section{Kaynakça}

Aksu, S. (2019). Drama ve argümantasyon yöntemlerinin ısı ve sıcaklık konusunun öğretiminde üniversite ögrrencilerinin kavramsal anlamalarına etkisi ve öğrencilerin yöntemlere yönelik tutumları (Yüksek lisans tezi). Yükseköğretim Kurulu Ulusal Tez Merkezi'nden edinilmiştir. (Tez No. 613995)

Aktamış, H. (2017). Örnek etkinliklerle fen eğitiminde argümantasyon [e-kitap sürümü]. https://ws1.turcademy.com/ww/webviewer.php?doc=18484 adresinden edinilmiştir.

Aktamış, H., \& Atmaca, A. C. (2016). Fen bilgisi öğretmen adaylarının argümantasyon tabanlı öğrenme yaklaşımına yönelik görüşleri. Elektronik Sosyal Bilimler Dergisi, 15(58), 936947.

Aldağ, H. (2006). Toulmin tartışma modeli. Çukurova Üniversitesi Sosyal Bilimler Enstitüsü Dergisi, 15(1), 13-34.

Altun, H., \& Aydın, S. (2019). Çağdaş yaklaşımlarla destekli fen öğretimi: Teoriden uygulamaya etkinlik örnekleri [e-kitap sürümü]. https://ws1.turcademy.com/ww/webviewer.php?doc=19088 adresinden edinilmiştir.

Apaydın, Z., \& Kandemir, M. A. (2018). İlkokulda sınıf öğretmenlerinin fen bilimleri dersinde argümantasyon yöntemi kullanımına ilişkin görüşleri. Journal of Computer and Education Research, 6(11), 106-122. 
Arık, M., \& Akçay, B. (2017). Argümantasyon tabanlı öğrenme. Pegem Atıf İndeksi, 177-191.

Aslan, S. (2010). Tartışma esaslı öğretim yaklaşımının öğrencilerin kavramsal algılamalarına etkisi. Kastamonu Ĕgitim Dergisi, 18(2), 467-500.

Aydemir, S., Karakaya-Cırıt, D., Kaya, S., \& Azger, C. (2018). Fen bilgisi öğretmen adaylarının argümantasyona ilişkin görüşleri ve argüman kurma becerilerinin araştırılması. Anemon Muş Alparslan Üniversitesi Sosyal Bilimler Dergisi, 6(STEMES'18), 131-138.

Aydın, Ö., \& Kaptan, F. (2014). Fen-teknoloji öğretmen adaylarının eğitimde argümantasyonun biliş üstü ve mantıksal düşünme becerilerine etkisi ve argümantasyona ilişkin görüşler. Ĕgitim Bilimleri Araştırmaları Dergisi, 4(2), 163-188.

Aymen-Peker, E., Apaydın, Z., \& Taş, E. (2012). Isı yalıtımını argümantasyonla anlama: İlköğretim 6. sınıf öğrencileri ile durum çalışması. Dicle Üniversitesi Sosyal Bilimler Enstitüsü Dergisi, 4(8), 79-100.

Biber, B. (2012). Fen ve teknoloji öğretmenlerinin yazmaya dair algıları ve öğrenme amaçl yazma aktivitelerini uygulama düzeyleri (Yüksek lisans tezi). Yükseköğretim Kurulu Ulusal Tez Merkezi'nden edinilmiştir. (Tez No. 319665)

Bilasa, P., \& Taşpınar, M. (2018). Argümantasyon tabanlı bilim öğrenme yaklaşımının öğretmen adaylarının eleştirel düşünme becerilerine ve tartışmaya olan isteklerine etkisi: Gazi Üniversitesi örneği. Kırşehir Eğitim Fakültesi Dergisi, 19(1), 555-577.

Bozkurt, O. (2012). Fen eğitiminde araştırmaya dayalı öğrenme yaklaşımının öğrencilerin akademik başarılarına ve bilimsel süreç becerilerine etkisi. Mustafa Kemal Üniversitesi Sosyal Bilimler Enstitüsü Dergisi, 9(18). 187-200.

Coşkun, E., \& Tiryaki, E. (2011). Tartışmacı metin yapısı ve öğretimi. Mustafa Kemal Üniversitesi Sosyal Bilimler Enstitüsü Dergisi, 8(16), 63-73.

Çakan-Akkaş, B. N., \& Kabataş-Memiş, E. (2020) Argümantasyon uygulamalarının 5. sınıf öğrencilerinin madde ve değişim ünitesi başarılarına ve bireysel değişimlerine yansıması. Kastamonu Ĕgitim Dergisi, 28(3), 1407-1417.

Çelik, T., Gökçe, S., Aydoğan-Yenmez, A., \& Özpınar, İ. (2017). Online argümantasyon: Eleştirel okuma özyeterlik algısı. Dil Ĕ̈itimi ve Araştırmaları Dergisi, 3(2), 117-134. 
Çetin, P. S., Kutluca, A. Y., \& Kaya, E. (2013). Öğrencilerin argümantasyon kalitelerinin incelenmesi. Fen Ĕgitimi ve Araştırmaları Derneği Fen Bilimleri Öğretimi Dergisi, 2(1), 56-66.

Çetinkaya, E., \& Taşar, M. F. (2017). Fen bilimleri eğitimi alanında Türkiye merkezli argümantasyon araştırmalarının çeşitli değişkenler açısından incelenmesi. Hacettepe University Journal of Education, 33(2): 353-381.

Demir, Z. (2019). Çevre eğitiminde argümantasyon uygulamalart ile zenginleştirilmiş 5e öğrenme metodunun 7. sını öğrencilerinin akademik başarılarına, eleştirel düşünme ve tartışma becerilerine etkisi (Yüksek lisans tezi). Yükseköğretim Kurulu Ulusal Tez Merkezi’nden edinilmiştir. (Tez No. 592194)

Demircioğlu, T., \& Uçar, S. (2012). Argüman-temelli sorgulama yönteminin fen ve teknoloji öğretmen adaylarının akademik başarısına ve bilimsel işlem becerilerine etkisinin incelenmesi. X. Ulusal Fen Bilimleri ve Matematik Eğitimi Kongresi’nde Sunulan Bildiri, Niğde, Türkiye.

Demirel, R. (2015). Argümantasyonun öğrencilerinin kavramsal anlama ve tartışma istekliklerine etkisi. Kastamonu Education Journal, 24(3), 1087-1108.

Demirel, T., Somyürek, S., \& Yılmaz, G. (2017). Ortaokul öğrencilerinin geometrik cisimler ve hacim ölçme konusuna yönelik yazılı argümantasyon becerilerinin incelenmesi. Ahi Evran Üniversitesi Kırşehir Eğitim Fakültesi Dergisi, 18(1), 191-211.

Erduran, D., \& Akçay, T. (2013). Fen ve teknoloji dersinde yazma etkinlikleri üzerine öğretmen görüşleri. Türk Fen Eğitimi Dergisi, 10(2), 48-65.

Erduran, S., Simon, S., \& Osborne, J. (2004). TAPping into argumentation: Developments in the application of Toulmin's argument pattern for studying science discourse. Science Education, 88(6), 915-933.

Erkol, M., Kışoğlu, M., \& Gül, Ş. (2017). Argümantasyon tabanlı bilim öğrenme yaklaşımı rapor formatının öğretmen adaylarının başarılarına ve fen bilgisi laboratuvarına yönelik tutumlarına etkisi. Elementary Education Online, 16(2). 
Eyceyurt-Türk, G., Tüysüz, M., \& Tüzün, Ü. N. (2018). Organik Kimya Kavramlarının Öğretiminde Düşünce Deneyleri Temelli Argümantasyonun Lise Öğrencilerinin Eleştirel Düşünme Becerilerine Etkisi. Kastamonu Eğitim Dergisi, 26(6), 2021-2032.

Güler, Ç. (2016). Fen laboratuvarı derslerinde kullanılan "argümantasyon tabanlı bilim öğrenme” yaklaşımının, fen bilgisi öğretmen adaylarının akademik başarılarına etkisi ve yaklaşım hakkındaki görüşleri (Yüksek lisans tezi). Yükseköğretim Kurulu Ulusal Tez Merkezi'nden edinilmiştir. (Tez No. 436750)

Günel, M., Kabataş-Memiş, E., \& Büyükkasap, E. (2010). Yaparak yazarak bilim öğrenmeYYBÖ yaklaşımının ilköğretim öğrencilerinin fen akademik başarısına ve fen ve teknoloji dersine yönelik tutumuna etkisi. Eğitim ve Bilim, 35(155), 49-62.

Günel, M., Kıngır, S., \& Geban, Ö. (2012). Argümantasyon tabanlı bilim öğrenme (ATBÖ) yaklaşımının kullanıldığı sınıflarda argümantasyon ve soru yapılarının incelenmesi. Eğitim ve Bilim, 37(164).

Hiğde, E., \& Aktamış, H. (2017). Fen bilgisi öğretmen adaylarının argümantasyon temelli fen derslerinin incelenmesi: Durum çalışması. Elementary Education Online, 16(1), 89-113.

İlk, A. (2019). Argümantasyon tabanlı bilim öğrenme (ATBÖ) yaklaşımının fen bilimleri dersinde ögrencilerin akademik başarısına ve tutumuna etkisi (Yüksek lisans tezi). Yükseköğretim Kurulu Ulusal Tez Merkezi'nden edinilmiştir. (Tez No. 552022)

Kabataş-Memiş, E. (2014). İlköğretim öğrencilerinin argümantasyon tabanlı bilim öğrenme yaklaşımı uygulamalarına ilişkin görüşleri. Kastamonu Eğitim Dergisi, 22(2), 400-418.

Kabataş-Memiş, E. (2017a). Türkiye'de argümantasyon konusunda gerçekleştirilen tezlerin analizi: Bir meta-sentez çalışması 1. Cumhuriyet International Journal of Education, 6(1), 47.

Kabataş-Memiş, E. (2017b). Argümantasyon uygulamalarına katılan öğretmen adaylarının küçük grup tartışmalarına ilişkin görüşleri. Kastamonu Ĕ̆itim Dergisi, 25(5), 2037-2056.

Kaçar, S. (2019). Fen bilimleri ögrretiminde argümantasyona dayalı sorgulama yöntemi kullanımının öğrencilerin epistemolojik inançlarına, üst biliş becerilerine ve kavramsal anlama düzeylerine etkilerinin araştırılması (Doktora tezi). Yükseköğretim Kurulu Ulusal Tez Merkezi’nden edinilmiştir. (Tez No. 553609) 
Karaer, G., Karademir, E., \& Tezel, Ö. (2019). Sınıf öğretmen adaylarının fen laboratuvarında argümantasyon tabanlı öğretime yönelik görüşlerinin incelenmesi. Eskişehir Osmangazi Üniversitesi Sosyal Bilimler Dergisi, 20(Özel Sayı), 217-241.

Kaya, O. N., \& Kılıç, Z. (2008). Etkin bir fen öğretimi için tartışmacı söylev. Ahi Evran Üniversitesi Kırşehir Eğitim Fakültesi Dergisi, 9(3), 89-100.

Keçeci, G., Kırılmazkaya, G., \& Kırbağ-Zengin, F. (2011). İlköğretim öğrencilerinin nükleer enerji sosyo-bilimsel konusunu online argümantasyon yöntemi ile öğrenmesi. Education Sciences, 7(2), 647-654.

Kırçiçek, H. (2019). Biyoloji laboratuvarı dersinde kullanılan argümantasyon tabanlı bilim ögrenme (ATBÖ) yaklaşımının fen bilgisi ögretmen adaylarının öz yeterliliklerine, tutumlarına ve argüman kalitelerine etkisi (Yüksek lisans tezi). Yükseköğretim Kurulu Ulusal Tez Merkezi’nden edinilmiştir. (Tez No. 585749)

Korkmaz, S. (2020). Teknoloji destekli argümantasyon tabanlı ögretimin öğretmen adaylarının teknolojik pedagojik alan bilgisi öz değerlendirmelerine ve kavramsal anlaylşlarina etkisi (Doktora tezi). Yükseköğretim Kurulu Ulusal Tez Merkezi'nden edinilmiştir. (Tez No. 631888)

Köseoğlu, F., Tümay, H., \& Budak, E. (2008). Bilimin doğası hakkında paradigma değişimleri ve öğretimi ile ilgili yeni anlayışlar. Gazi University Journal of Gazi Educational Faculty (GUJGEF), 28(2).

Küçük, H., \& Aycan, H. Ş. (2014). 2007-2012 yılları arasında bilimsel tartışma üzerine gerçekleştirilmiş açık erişim araştırmaların bir incelemesi. Muğla Sitkı Koçman Üniversitesi Eğitim Fakültesi Dergisi, 1(1).

Millî Eğitim Bakanlığı. (MEB). (2005). İlköğretim fen ve teknoloji dersi 4 ve 5. sinıflar öğretim programı. Ankara: MEB Yayınları.

Namdar, B., \& Demir, A. (2017). Örümcek mi böcek mi? 5. sınıf öğrencileri için argümantasyon tabanlı sınıflandırma etkinliği. Journal of Inquiry Based Activities, 6(1), 1-9.

Namdar, B., \& Tuskan, İ. B. (2018). Fen bilgisi öğretmenlerinin argümantasyona yönelik görüşleri. Hacettepe Üniversitesi Eğitim Fakültesi Dergisi, 33(1), 1-22. 
Öğreten, B., \& Uluçınar-Sağır, Ş. (2014). Argümantasyona dayalı fen öğretiminin etkililiğinin incelenmesi. Journal of Turkish Science Education, 11(1), 75-100.

Özcan, R., Aktamış, H., \& Hiğde, E. (2018). Fen bilimleri derslerinde kullanılan argümantasyon düzeyinin belirlenmesi. Pamukkale Üniversitesi Ĕ̈itim Fakültesi Dergisi, 43, 93-106.

Sevgi, Y., \& Şahin, F. (2017). Gazete haberlerindeki sosyobilimsel konuların argümantasyon yöntemiyle tartışılmasının 7. sınıf öğrencilerinin eleştirel düşünme becerileri üzerine etkisi. Journal of Human Sciences, 14(1), 156-170.

Süküt, E. (2020). İlkokul dördüncü sınıf ögrrencilerinin yaratıcı drama ile yapılandırılmış argümantasyona dayalı besinlerimiz ünitesindeki argümanları ve derse ilişkin görüşleri (Yüksek lisans tezi). Yükseköğretim Kurulu Ulusal Tez Merkezi’nden edinilmiştir. (Tez No. 630105)

Şahin, F., \& Hacıoğlu, Y. (2010, November). Bilimsel tartışma destekli örnek olayların 8. sınıf öğrencilerinin "kalıtım" konusunda kavram öğrenmelerine ve okuduğunu anlama becerilerine etkisi. In International conference on new trends in education and their implications (No. s 269275).

Topçu, M. S., \& Atabey, N. (2017). Sosyobilimsel konu içerikli alan gezilerinin ilkögretim ögrencilerinin argümantasyon nitelikleri üzerine etkisi. Bartin Üniversitesi Egitim Fakültesi Dergisi, 6(1), 68.

Torun, F., \& Şahin, S. (2016). Argümantasyon temelli sosyal bilgiler dersinde öğrencilerin argüman düzeylerinin belirlenmesi. Eğitim ve Bilim, 41(186).

Toulmin, S. (2003). The uses of argument. Cambridge-UK: Cambridge University Pres.

Tümay, H. (2008). Argümantasyon odaklı kimya eğitimi (Doktora tezi). Yükseköğretim Kurulu Ulusal Tez Merkezi'nden edinilmiştir. (Tez No. 350221)

Tümay, H., \& Köseoğlu, F. (2010). Bilimde argümantasyona odaklanan etkinliklerle kimya öğretmen adaylarının bilimin doğası hakkındaki anlayışlarını geliştirme. Gazi University Journal of Gazi Educational Faculty (GUJGEF), 30(3). 
Türkmenoğlu, M., \& Çopur, E. (2021). Sınıf öğretmenlerinin argümantasyona ilişkin görüşlerinin ve argüman oluşturma düzeylerinin incelenmesi. Uluslararası Temel Eğitim Çalışmaları Dergisi, 1, 29-42.

Uysal, Y. (2014). Argümantasyon. Erişim adresi: https://prezi.com/it77vx4qe-c4/argumantasyon/ adresinden erişilmiştir.

Webster's Online Dictionary. (t.y.). Argumentation. Erişim adresi: https://www.merriamwebster.com/dictionary/argumentation. adresinden erişilmiştir.

Yakmac1-Güzel, B., Erduran, S., \& Ardaç, D. (2009). Aday kimya öğretmenlerinin kimya derslerinde bilimsel tartışma (argümantasyon) tekniğini kullanımları. Boğaziçi Üniversitesi Eğitim Dergisi, 26(2), 33-48.

Yeşildağ-Hasançebi, F., \& Günel, M. (2013). Argümantasyon tabanlı bilim öğrenme yaklaşımının dezavantajı öğrencilerin fen bilgisi başarılarına etkisi. Ilkogretim Online, 12(4).

Yıldırım, A., \& Şimşek, H. (2018). Sosyal bilimlerde nitel araştırma yöntemleri (11. Baskı). Ankara: Seçkin Yayıncılık.

Yüksel, Y (2019). Argümantasyon tabanlı biyoloji ögretiminin başarı, tutum ve eleştirel düşünme becerisi üzerine etkisi (Doktora tezi). Yükseköğretim Kurulu Ulusal Tez Merkezi'nden edinilmiştir. (Tez No. 552512) 